\title{
DAUR ULANG PASIR SILIKA BEKAS INTI COR MELALUI TEKNIK BALL MILL UNTUK MENGEMBALIKAN DAYA IKATNYA
}

\author{
Sugeng Slamet \\ Fakultas Teknik, Program Studi Teknik Mesin \\ Universitas Muria Kudus \\ Email: sugeng.slamet@umk.ac.id \\ M.Yanuwar. A.R. Bastian \\ Fakultas Teknik, Program Studi Teknik Mesin \\ Universitas Muria Kudus \\ Email: yanuarbastian064@gmail.com
}

\begin{abstract}
ABSTRAK
Teknik pengecoran merupakan metode pembentukan material logam yang sudah lama dikenal oleh manusia. Metode ini mempunyai banyak keuntungan yaitu dapat menghasilkan benda sesuai dengan aslinya, tidak dibatasi leh ukuran dan sesuai untuk produk massal. Media yang sering digunakan adalah pasir dan sebagian pola dilengkapi dengan inti cor. Pasir silika digunakan pengrajin cor untuk membuat inti cor. Pasir silika ini hanya bisa digunakan untuk sekali pakai untuk satu cetakan. Pasir silika tidak dapat digunakan lagi karena tidak mempunyai daya ikat antar partikelnya. Metode yang dilakukan adalah menghancurkan kembali bongkahan pasir inti bekas cor ke dalam mesin ball mill dengan variasi kecepatan putar, waktu giling, diameter dan jumlah bola baja yang digunakan per 1000 gr. Pasir silika selanjutnya dilakukan pengayakan dengan menggunakan mesh 100 dan 150. Hasil penggilingan dengan teknik ball mill menunjukkan bahwa kecepatan putar mesin ball mill yang meningkat tidak secara signifikan meningkatkan prosentase hasil. Penambahan waktu giling mampu meningkatkan prosentase hasil untuk semua ukuran mesh. Penambahan waktu giling dari 30 menjadi 60 menit pada kecepatan putar yang sama dan penambahan diameter bola dari 20 menjadi $25 \mathrm{~mm}$ mampu meningkatkan 14,10\% lebih tinggi pada mesh 100. Perlakuan yang sama dengan mesh 150 terjadi peningkatan sebesar 3,88\%. Pasir silika daur ulang digunakan untuk membuat kembali inti cor. Semakin kecil ukuran mesh pasir silika menunjukkan ikatan partikel yang lebih kuat dengan bentuk pola inti yang lebih sempurna.
\end{abstract}

Kata kunci: ball mill, pasir silika, inti cor, pengecoran logam, mesh.

\begin{abstract}
Casting technique is a method of forming metal material that has long been known by humans. This method has many advantages that can produce objects in accordance with the original, not limited to size and suitable for bulk products. Media that is often used is sand and some patterns are equipped with cast core. Silica sand is used to make cast core. This silica sand can only be used for single use for one mold. cast core silica sand is not usable again because it has no binding power. The method used is to destroy the cast core again into ball mill machine with variation of rotation speed, milling time, diameter and number of steel balls used per 1000 gr. The silica sand is further carried out by using mesh 100 and 150 . The results with ball mill technique show that the speed of rotary ball mill machine increased not significantly increase the percentage of results. The addition of milling time can increase the yield percentage for all mesh sizes. The addition of milling time from 30 to 60 minutes at the same rotational speed and the addition of spherical diameter from 20 to $25 \mathrm{~mm}$ can increase $14.10 \%$ higher at mesh 100 . The same treatment with mesh 150 has increased by $3.88 \%$. Recycled silica sand is used to rebuild the cast core. The smaller the size of the silica sand mesh shows stronger particle bonds with a more perfect core shape.
\end{abstract}

Keywords: ball mill, Silica sand, Cast core, Casting, mesh.

\section{PENDAHULUAN}

Teknik pengecoran logam merupakan salah satu teknik pembentukan logam yang sudah lama dikenal manusia. Pengecoran dengan menggunakan cetakan pasir merupakan media pengecoran logam tertua. Berbagai macam komponen permesinan dan perabotan dari logam dapat dikerjakan melalui teknik pengecoran logam[1]. Keuntungan menggunakan teknik pengecoran logam adalah menghasikan produk 
yang identik dengan aslinya, sesuai untuk produk ukuran besar dan kecil, sesuai untuk semua jenis logam, biaya produksi relatif murah dan sesuai untuk produk massal. Selain keuntungan tersebut, teknik pengecoran logam mempunyai kelemahan yaitu permukaan produk yang dihasilkan relatif kasar, terbentuk porositas dan penyusutan. Permukaan kasar tersebut dapat dibenahi melalui proses permesinan. Porositas dapat dikurangi dengan menentukan temperatur tuang yang sesuai, menempatkan saluran pembuangan udara pada cetakan dan menghindari turbulensi aliran saat penuangan logam cor ke dalam cetakan. Penyusutan dapat ditanggulangi dengan menempatkan saluran penambah/riser[2].

Kebutuhan utama teknik pengecoran adalah pola, cetakan dan inti cor. Teknik pengecoran logam diklasifikasikan berdasarkan cetakan terdiri atas cetakan permanen dan cetakan non permanen. Cetakan permanen dibuat dari material logam dan dapat digunakan terus menerus. Cetakan non pemanen merupakan cetakan yang dibuat untuk sekali proses. Media cetakan non permanen dbuat dengan menggunakan pasir cetak, styrofoam, lilin dan keramik. Cetakan pasir digunakan pada industri pengecoran dikarenakan mampu menghasilkan produktifitas tinggi, biaya murah dengan proses yang sederhana [3]. Selain pasir untuk membuat cetakan, juga dibutuhkan pasir silika untuk membuat inti cor. Inti cor ditempatkan pada cetakan untuk memisahkan bagian yang tidak dialiri logam cor, misalnya untuk membuat rongga pada produk cor. Pasir silika untuk inti cor mempunyai kemampuan ikat yang kuat ketika dibakar. Kemampuan ikat inilah yang menyebabkan pasir silika inti cor mampu menahan logam cair yang masuk ke dalam cetakan. Produk dengan dimensi tipis dan komplek biasanya dikerjakan melalui teknik pengecoran investment casting. Teknik pengecoran ini membutuhkan biaya produksi yang tinggi, rumit dan prosesnya lama. Cetakan pasir mampu menahan temperatur tinggi dan menghasilkan produk cor berdinding tipis dengan menggunakan pengikat/binder anorganik seperti silika (SiO2), sodium hydroxide $(\mathrm{NaOH})$ dan sodium okside $(\mathrm{Na} 2 \mathrm{O})$. Karakteristik penting dari pasir sebagai bahan refraktori alami adalah mampu menahan suhu tinggi saat bertemu dengan cairan logam dan terjadi penggabungan dengan cairan[4].

Pasir silika untuk inti cor hanya dapat digunakan untuk sekali pengecoran. Daya ikat partikel pasir silika bekas inti cor akan menurun setelah digunakan untuk pengecoran. Limbah pasir silika bekas inti cor banyak ditemukan di lokasi industri pengecoran logam di daerah Juwana-Kabupaten Pati. Pasir pantai di Indonesia umumnya berwarna putih dan cenderung mengandung material berupa pasir kuarsa atau pasir silika. Pasir silika terdiri atas kristal-kristal silika ( $\mathrm{SiO} 2)$ dan mengandung senyawa pengotor seperti oksida besi, oksida kalsium, oksida alkali, oksida magnesium, tanah liat dan zat organik hasil sisa-sisa hewan serta tumbuhan[5]. Pasir silika yang terdapat di alam dapat diubah ukurannya menjadi skala nanometer yang disebut dengan nanopartikel silika. Nanopartikel merupakan partikel yang memiliki ukuran $<100 \mathrm{~nm}$. Nanopartikel silika memiliki beberapa keunggulan yaitu luas permukaan terhadap volume lebih besar, ketahanan panas yang baik, kekuatan mekanik yang tinggi dan inert sehingga digunakan sebagai prekursor katalis, absorben dan filter komposit[6]. Gambar 1. menunjukkan limbah pasir silika bekas inti cor.

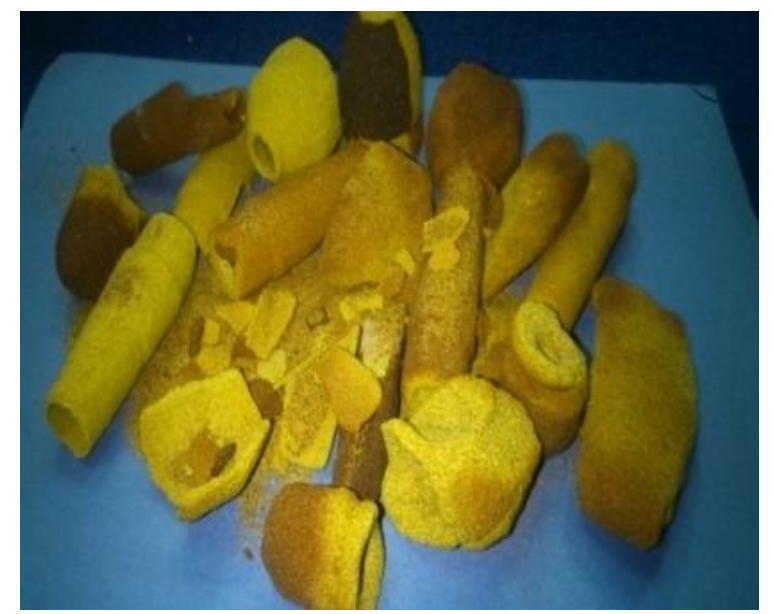

Gambar 1. Pasir Silika Bekas Inti Cor

Metalurgi serbuk merupakan salah satu metode untuk mengolah material menjadi komponen. Teknik yang digunakan adalah membuat serbuk dengan berbagai distribusi ukuran dengan perbandingan tertentu. Proses metalurgi serbuk secara umum dilakukan dengan menggiling (blending), mencampur bahan baku (mixing) dan memanaskan produk awal yang lebih dikenal dengan proses sintering. Gambar 2. menunjukkan berbagai bentuk butir pasir. 


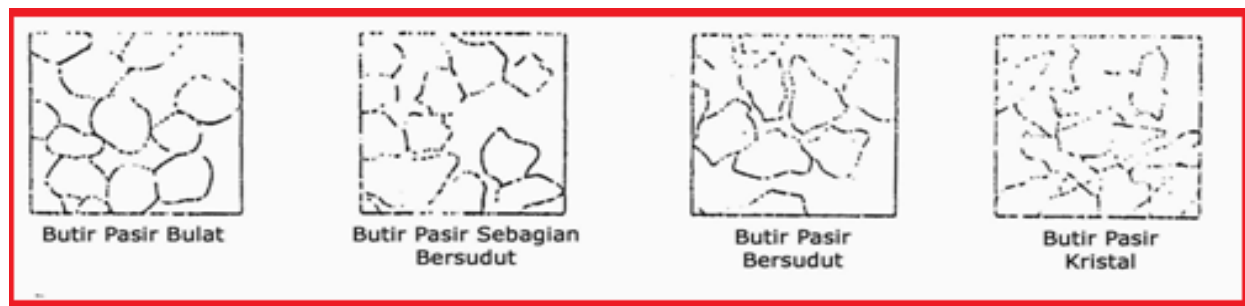

Gambar 2. Berbagai Bentuk Butir Pasir [7]

Proses pembuatan serbuk dengan teknik ball mill terdapat beberapa parameter yang dapat mempengaruhi hasil serbuk yaitu kecepatan dan variasi jumlah bola penumbuk. Semakin tinggi kecepatan putar drum ball mill akan meningkatkan tumbukan antara bola penumbuk dan serbuk. Saat bola penumbuk berputar hingga kelintasan atas, maka bola baja akan jatuh menumbuk serbuk sehingga meningkatkan kehalusan serbuk. Namun apabila kecepatan semakin tinggi dan melebihi batas maksimum maka yang akan terjadi pada bola dan bahan akan terpisah dan terjadi pinned pada dinding bagian dalam sehingga bola-bola penumbuk tidak jatuh dan tidak menghasilkan tumbukan yang maksimal[8]. Pembuatan serbuk logam dengan metode mekanik yaitu crushing dan milling dapat menggunakan teknik ball mill yaitu mesin yang digunakan untuk menghancurkan bahan menjadi serbuk yang sangat halus dengan bantuan bola-bola baja. Pembuatan serbuk aluminium dari scrap aluminium foil dapat dilakukan dengan teknik ball mill. Semakin besar ukuran bola penumbuk akan meningkatkan kualitas serbuk yang baik. Hal ini disebabkan dampak energi tumbukan yang lebih besar saat proses grinding[9].

Pada proses pembuatan serbuk duralumin menunjukkan bahwa diameter bola $25 \mathrm{~mm}$ akan menghasilkan ukuran mesh yang lebih besar dibanding diameter $35 \mathrm{~mm}$. Ukuran diameter bola baja lebih besar cenderung membentuk partikel menyerupai kripik (flaky), sedangkan pada diameter bola baja 25 mm dengan mesh 100 berbentuk bulat[10]. Ukuran partikel pasir yang lebih kecil juga akan meningkatkan nilai kekerasan dan struktur mikro besi cor kelabu pada pengecoran evaporatif[11]. Teknik penggilingan dengan alat Fritsch Planetary Ball mill, dilakukan dengan tujuan memperkecil ukuran partikel pasir sehingga lebih mudah ditekan dan dicetak. Teknik ini menggunakan kecepatan penggilingan 150 putaran selama 1 jam menggunakan bola zirconia. Setelah itu pasir diayak dengan menggunakan mesh 120 untuk mendapatkan ukuran partikel yang lebih homogen. Unsur pengotor yang terdapat dalam pasir silika dihilangkan menggunakan magnet permanen[12].

Pasir silika bekas ini cor ini dapat digunakan kembali dengan cara mendaur ulang. Proses daur ulang dilakukan dengan menggiling kembali bongkahan pasir silika menjadi partikel. Teknik ball mill dapat digunakan untuk mengurai bongkahan pasir silika bekas inti menjadi serbuk halus. Gambar 3. menunjukkan mekanisme teknik ball mill.

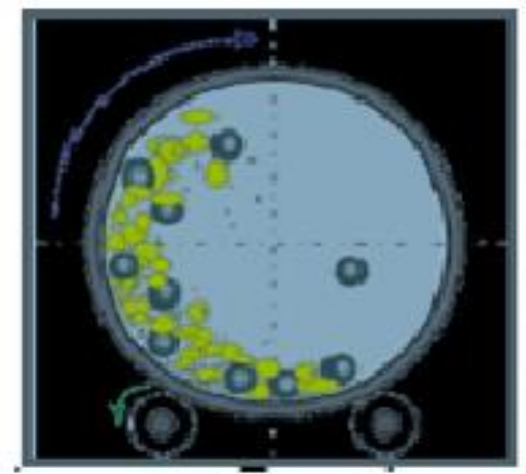

(a)

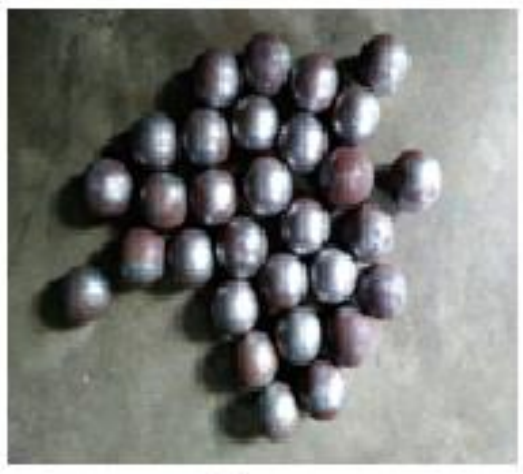

(b)

Gambar 3. Teknik Ballmill (A) Proses Mekanik Ball Mill (B) Bola-Bola Baja [10].

\section{METODOLOGI PENELITIAN}

Penelitian ini melakukan proses daur ulang pasir silika bekas inti cor. Proses daur ulang dilakukan dengan cara mengurai kembali bongkahan pasir silika bekas inti cor menjadi serbuk pasir. Metode yang digunakan yaitu dengan teknik ball mill menggunakan bola-bola baja di dalam drum baja yang berputar dengan kecepatan tertentu menggunakan motor listrik.

Adapun variabel dalam penelitian ini meliputi : kecepatan putar drum 200 dan $350 \mathrm{rpm}$, waktu penggilingan 30 dan 60 menit, diameter bola baja $20 \mathrm{~mm}$ dan $25 \mathrm{~mm}$. Berat pasir silika bekas inti cor yang diolah per 1000 gr. Gambar 4. menunjukkan mesin ball mill yang digunakan dalam penelitian ini. 


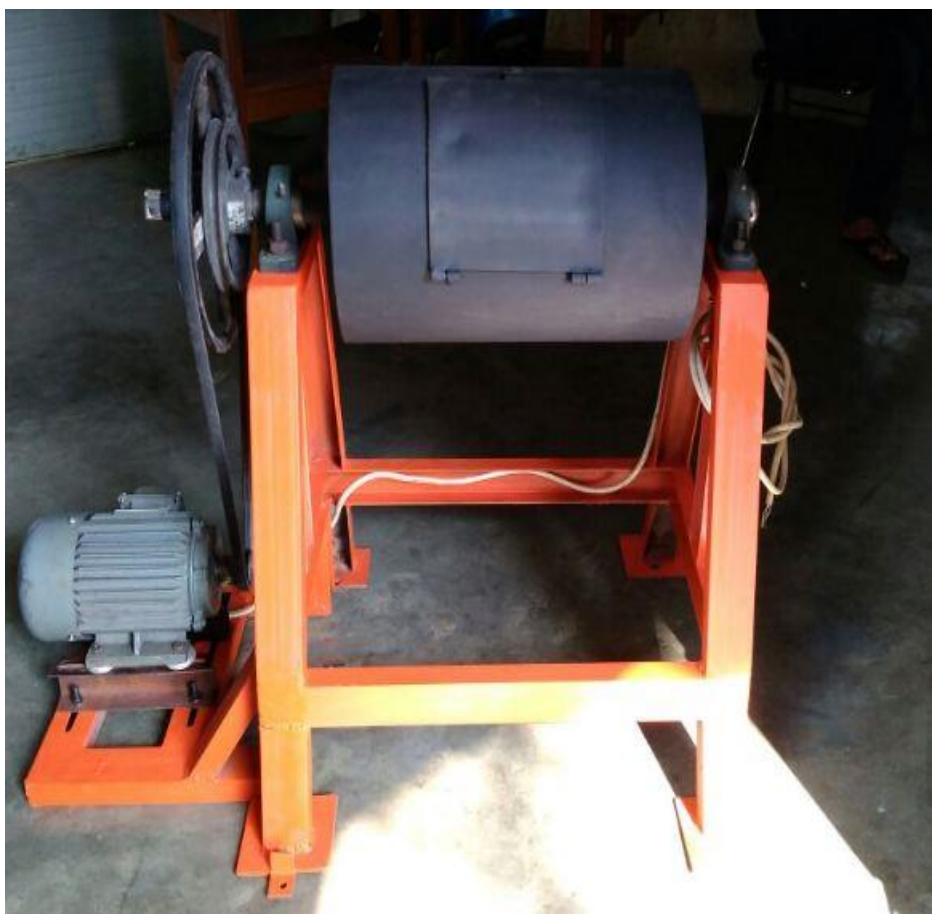

Gambar 4. Mesin Ballmill

Pengujian terhadap hasil eksperiman dilakukan dengan mengayak serbuk pasir silika menggunakan ukuran mesh 100 dan 150. Jumlah serbuk pasir yang lolos mesh tersebut dihitung dengan menggunakan persamaan 1 .

$\% \mathrm{n}=\frac{W \text { hasil }}{\text { W sampel uji }} \times 100 \%$

\section{HASIL DAN PEMBAHASAN}

Setelah dilakukan eksperimen dalam penelitian ini, didapatkan data hasil sebagaimana ditunjukkan tabel 1 .

Tabel 1. Hasil pengolahan pasir silika bekas inti cor dengan teknik ball mill

\begin{tabular}{|c|c|c|c|c|c|c|}
\hline $\begin{array}{c}\text { Kecepatan } \\
(\text { Rpm })\end{array}$ & $\begin{array}{c}\text { Waktu } \\
\text { penggilingan } \\
(\text { mnt })\end{array}$ & $\begin{array}{c}\text { Diameter bola } \\
\text { baja }(\mathrm{mm})\end{array}$ & $\begin{array}{c}\text { Mesh-100 } \\
(\%)\end{array}$ & $\begin{array}{c}\text { Mesh-150 } \\
(\%)\end{array}$ & $S D-100$ & $S D-150$ \\
\hline \multirow{4}{*}{200} & \multirow{3}{*}{30} & 20 & 17.23 & 5.10 & 1.41 & 0.07 \\
\hline & & 25 & 19.23 & 5.20 & \multirow{3}{*}{0.24} & \multirow{3}{*}{0.45} \\
\hline & & 20 & 20.63 & 5.03 & & \\
\hline & 60 & 25 & 20.97 & 5.67 & & \\
\hline \multirow{4}{*}{350} & \multirow{3}{*}{30} & 20 & 7.83 & 1.73 & 1.98 & 1.11 \\
\hline & & 25 & 10.63 & 3.30 & \multirow{3}{*}{3.18} & \multirow{3}{*}{0.75} \\
\hline & & 20 & 9.57 & 2.37 & & \\
\hline & 60 & 25 & 14.07 & 3.43 & & \\
\hline
\end{tabular}

Pada tabel 1. menunjukkan hasil daur ulang pada mesin ball mill yang dilakukan dengan melakukan variasi kecepatan putar (Rpm), waktu penggilingan (menit) dan diameter bola baja (mm). Hasil daur ulang pasir silika daur ulang ini dipisahkan dengan mengayak serbuk pasir menggunakan ukuran mesh 100 dan mesh 150.

Kecepatan putar mesin ball mill yang meningkat tidak secara signifikan meningkatkan prosentase hasil, namun penambahan waktu giling mampu meningkatkan prosentase hasil untuk semua ukuran mesh. Penambahan waktu giling dari 30 menjadi 60 menit pada kecepatan putar yang sama dan penambahan diameter bola dari 20 menjadi $25 \mathrm{~mm}$ mampu meningkatkan 14,10\% lebih tinggi pada mesh 100. Perlakuan yang sama dengan mesh 
150 terjadi peningkatan sebesar 3,88\%. Sebaran data dari pengujian yang dilakukan pada mesh 100 dan mesh 150 menunjukkan bahwa mesh 150 mempunyai standart deviasi (SD) dengan nilai lebih kecil. Hal ini menunjukkan bahwa data hasil pengujian mempunyai tingkat akurasi yang baik.

Peningkatan kecepatan putar dari 200 menjadi 350 Rpm pada mesin ball mill menurunkan prosentase hasil daur ulang pasir silika sebesar 46,06\% pada mesh 100 dan 48,43\% pada mesh 150 . Prosen hasil daur ulang pasir silika terhadap waktu giling pada beberapa kecepatan putar dan ukuran mesh ditunjukkan pada gambar 5 .

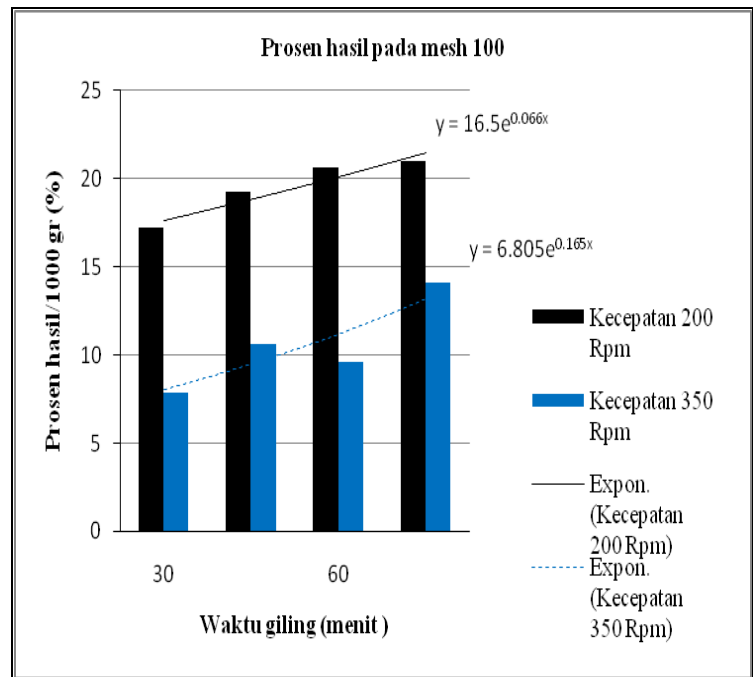

(a)

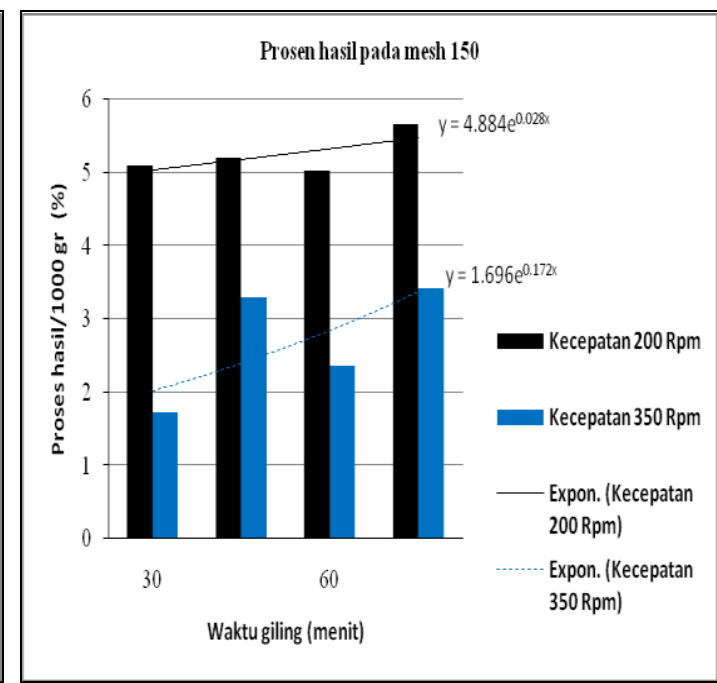

(b)

\section{Gambar 5. Prosen Hasil Daur Ulang Pasir Silika Dengan Teknik Ball Mill (A) Mesh 100 (B) Mesh 150}

Teknik ball mill yang digunakan untuk mendaur ulang pasir silika bekas inti cor cukup efektif mampu mengecilkan ukuran partikel. Semakin besar ukuran mesh, hasil yang didapatkan semakin menurun. Hal ini disebabkan semakin besar ukuran mesh, ukuran partikel yang mampu lolos mesh semakin kecil dan halus. Penelitian lebih lanjut teknik ball mill dapat dilakukan untuk dapat meningkatkan hasil pada mesh yang lebih besar dengan ukuran partikel yang semakin kecil. Partikel dengan ukuran mikro mempunyai sifat fisis dan mekanis yang berbeda dengan partikel dalam ukuran makro.

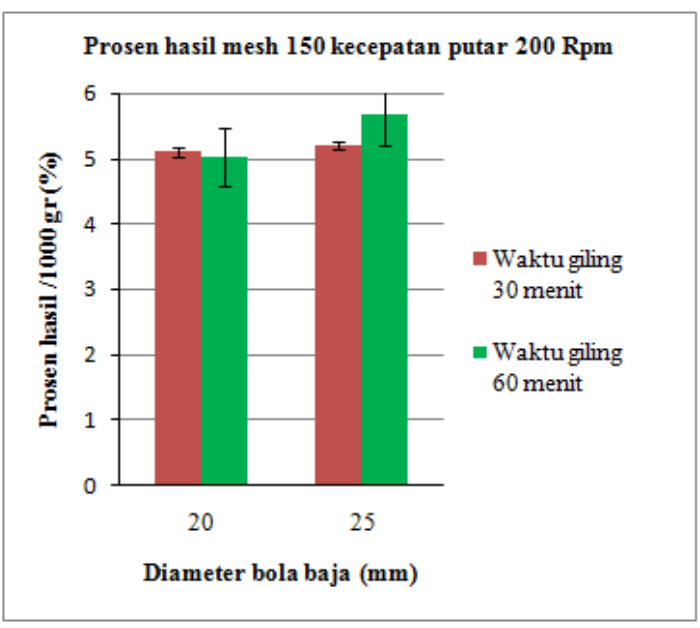

(a)

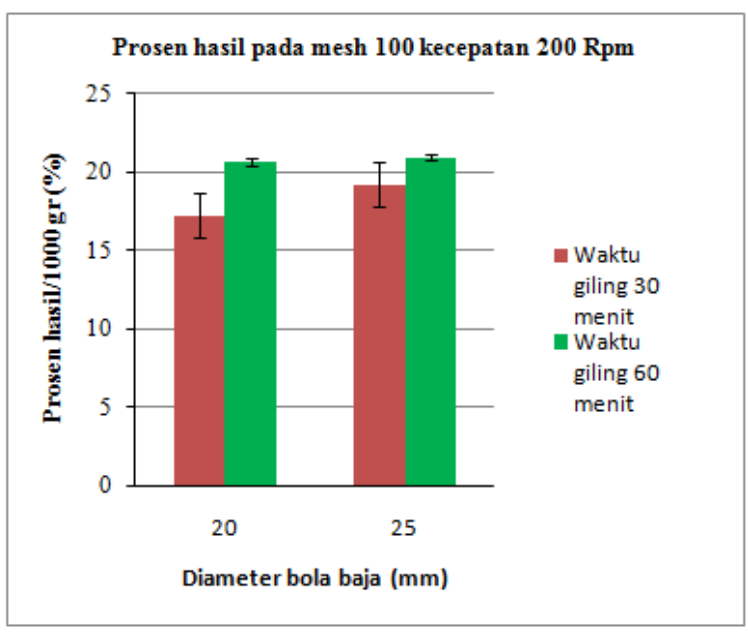

(b) 


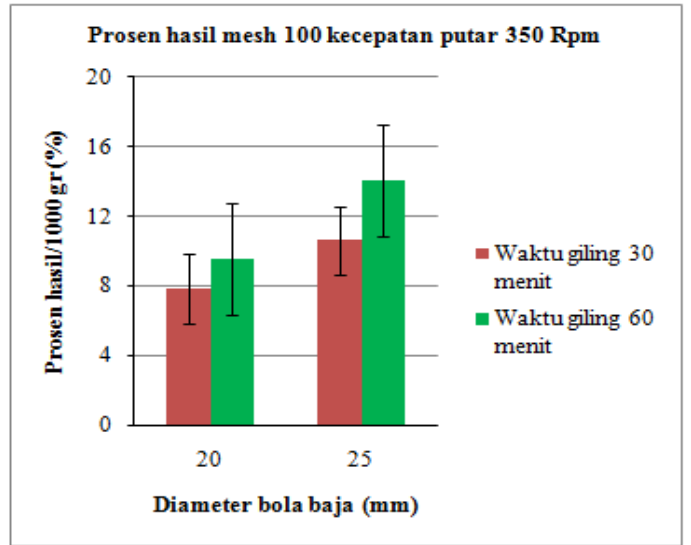

(c)

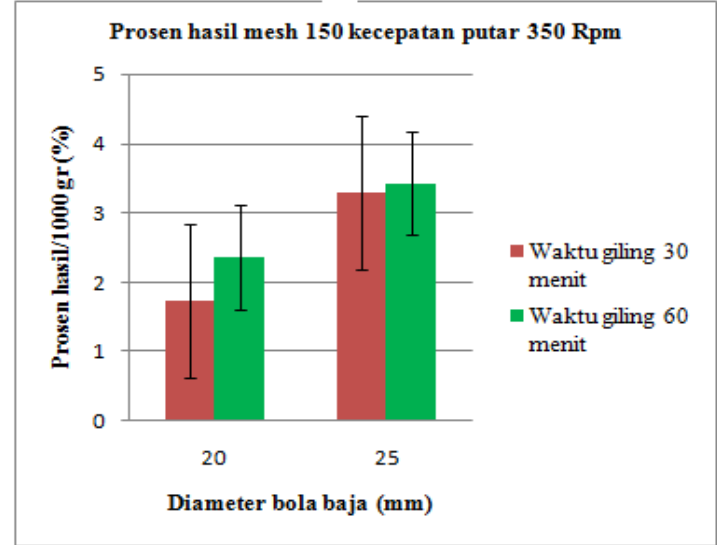

(d)

Gambar 6. Prosen Hasil Terhadap Kecepatan Putar (A) Mesh 150 Kecepatan Putar 200 Rpm (B) Mesh 100 Kecepatan Putar 200 Rpm (C) Mesh 100 Kecepatan Putar 350 Rpm (D) Mesh 150 Kecepatan Putar 350 Rpm

Teknik ball mill merupakan upaya untuk mengembalikan sifat fisis dan mekanis pasir silika bekas ini cor untuk dapat dipergunakan lagi. Teknik ball mill relatif sederhana dengan kemampuan untuk mengolah pasir silika bekas ini cor secara maksimal. Teknik ball mill ini dapat dikembangkan dalam berbagai tipe penggerak dan volume drum untuk memaksimalkan hasil. Semakin kecil ukuran partikel akan dapat mengembalikan daya ikat pasir silika bekas inti cor. Prosen hasil secara rinci pada setiap kecepatan putar mesin ball mill terhadap ukuran mesh, sebagaimana ditunjukkan pada gambar 6.

Pasir silika hasil daur ulang selanjutnya digunakan untuk membuat produk inti cor. Selain pengujian terhadap kapasitas hasil dan ukuran partikel pasir silika, pengujian juga dilakukan terhadap produk inti cor menggunakan pasir silika bekas inti. Hal ini dilakukan untuk mengetahui daya ikat antar partikel pasir silika yang dihasilkan dari proses daur ulang. Kekuatan ikat antar partikel yang baik menunjukkan kualitas inti cor yang baik pula. Proses pembuatan inti cor dimulai dari hasil pengayakan pasir silika, pencetakan inti sesuai pola yang diinginkan, pembakaran inti dan mengukur bobot inti cor. Tahapan proses tersebut sebagaimana ditunjukkan pada gambar 7 .

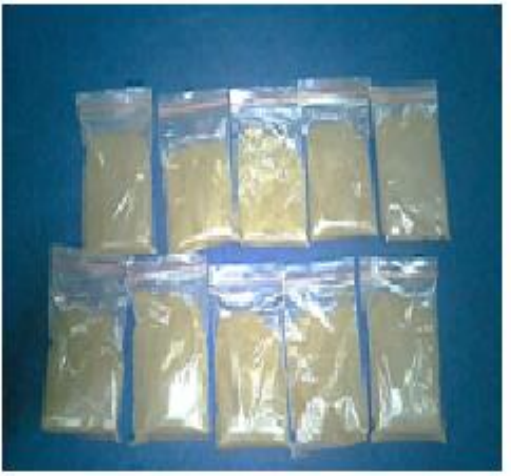

(a)

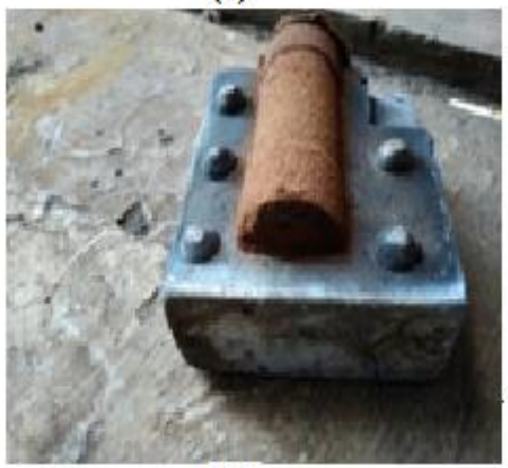

(c)

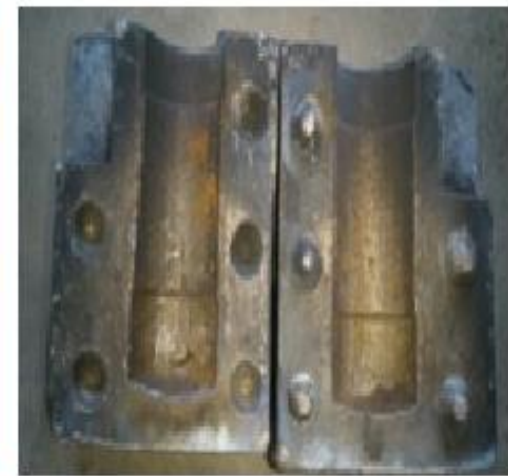

(b)

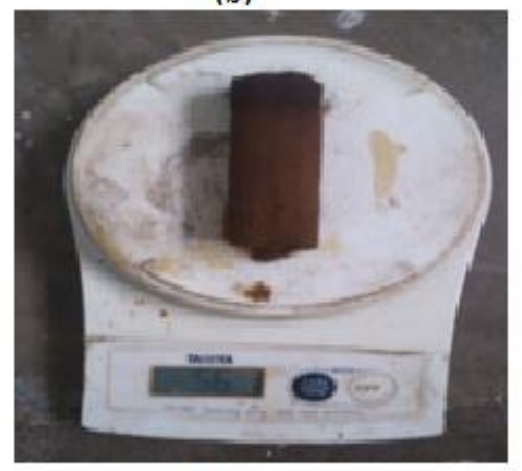

(d)

Gambar 7. Pembuatan Inti Cor (A) Pasir Silika Proses Daur Ulang (B) Cetakan Inti Cor (C) Inti Cor Hasil Pembakaran (D) Mengukur Bobot Inti Cor 
Pengujian yang dilakukan pada pasir silika bekas inti cor yang lolos mesh 100 dan mesh 150 untuk specimen inti cor produk intake manifold menunjukkan hasil yang baik. Inti cor yang dibuat dengan menggunakan pasir silika daur ulang dapat terikat baik dengan daya ikat yang cukup kuat ditandai dengan tidak banyak pasir silika yang lepas. Inti cor dari partikel pasir silika lolos mesh 100 mempunyai berat 56 gram dan lolos mesh 150 mempunyai berat 60 gram. Perbedaan berat yang ada menunjukkan bahwa mesh 100 mempunyai daya ikat kurang kuat, dimana sebagian partikel pasir inti masih dapat terlepas dari produk inti cor. Inti cor dari pasir silika mesh 100 terdapat rongga-rongga berupa porositas dengan densitas yang lebih rendah. Produk inti cor pada pasir silika lolos mesh 150 menunjukkan daya ikat partikel lebih kuat. Produk inti cor ini mempunyai densitas lebih besar dengan porositas yang lebih kecil. Inti cor merupakan bagian penting pada produk cor. Inti cor yang cacat akan menghasilkan produk cor yang cacat pula. Bentuk cacat produk cor yang disebabkan tidak sempurnanya inti dapat berupa penyusutan volume benda kurang, kepresisian rendah dan permukaan benda kasar. Proses daur ulang pasir silika bekas inti cor dengan menggunakan teknik ball mill ini dapat mengurangi biaya produksi khususnya pembelian pasir silika baru. Penurunan biaya produksi bagi industri pengecoran logam akan berdampak pada peningkatan daya saing produk dan meningkatkan kesejahteraan pengrajin.

\section{KESIMPULAN} berikut :

Penelitian proses daur ulang pasir silika bekas inti cor dengan teknik ball mill dapat disimpulkan sebagai

a. Teknik ball mill dapat digunakan sebagai metode untuk mendaur ulang pasir silika bekas inti cor sehingga dapat digunakan kembali.

b. Peningkatan kecepatan putar mesin ball mill tidak secara signifikan meningkatkan kapasitas hasil pasir silika daur ulang. Kecepatan putar yang tinggi justru menurunkan kapasitas dan ukuran pasir silika inti cor.

c. Peningkatan ukuran mesh dari mesh 100 ke mesh 150 menurunkan kapasitas hasil daur ulang, namun pada mesh 150 kualitas inti cor yang dihasilkan lebih baik.

d. Peningkatan diameter bola baja dan waktu giling meningkatkan kapasitas hasil pada putaran mesin 200 Rpm, sedangkan pada putaran 350 rpm tidak memberikan dampak terhadap peningkatan hasil.

e. Daya ikat antar partikel pasir silika bekas inti cor dengan mesh 150 mempunyai kekuatan yang lebih baik dengan porositas yang lebih kecil.

\section{UCAPAN TERIMA KASIH}

Terima kasih kami sampakan atas kerjasama yang terjalin baik dalam menyelesaikan penelitian ini.

a. UD. Budi Jaya Logam, Desa Sejomulyo, Garuan Kec. Juwana Kabupaten Pati.

b. Laboratorium teknik pengecoran logam, Program studi teknik mesin, Universitas Muria Kudus.

\section{DAFTAR PUSTAKA}

[1] Sulaiman S dan Hamouda A.M.S, 2004., Modelling and experimental investigation of solidification process in sand casting., Journal of material processing technology 155-156 (2004), pp. 1723-1726.

[2] Sachin L, Nimbulkar dan Rajendra S. Dalu., 2016., Design optimization of gating and feeding system through simulation technique for sand casting of wear plate, Perspective in Science (2016)8, pp.39-42.

[3] Eun Hee Kim., Guen Ho Cho., Yoon Suk Oh., Yeon Gil Junga., 2016., Development of high temperature mold process for sand casting with a thin and complex shape, Thin Solid Film 620 (2016), pp. 70-75.

[4] Campbell, J., 2000., Casting., Birmingham Universty., United Kingdom.

[5] Fairus., Sirin., Haryono., Sugita H., M., Sudrajat Agus., 2009., Proses Pembuatan Waterglass dari Pasir Silika dengan Pelebur Natrium Hidroksida, Jurnal Teknik Kimia Indonesia,Vol. 8, No. 2, hal. 56-62.

[6] Kalapathy., Proctor, A., Shultz, J., 2000., A Simple Method For Production of Pure Silica FromRice Hull Ash, Bioresource Technology, Vol. 73, hal. 257-262.

[7] Surdia Tata dan Chijiwa Kenji., 1975., Teknik pengecoran logam., Jakarta., Pradnya Paramitha.

[8] Suryanarayana. C., 200., Mechanical balloyingand milling, Department of Metallurgi caland Materials Engineering., Colorado School of Mines. 
[9] Seong Hyeon Hong., 2011. Manufacturing of aluminum flake powder from foil scrap by dry ballmilling process, Department of Materials Engineering, Korea Institute ofMachinery and Materials, 66 Sangnam, South Korea.

[10] Tasha Oksaria dan Wahyono Suprapto., 2014, Pengaruh kecepatan putar drum dan jumlah bola penumbuk pada ball mill terhadap distribusi ukuran serbuk duralumin, Teknik Mesin, Fakultas Teknik, Universitas Brawijaya, Malang.

[11] Sutiyoko dan Lutiyatmi., 2013., Pengaruh ukuran pasir cetak terhadap fluiditas dan akurasi ukuran besi cor kelabu dengan pengecoran lost foam, Teknik Mesin, Politeknik Manufaktur Ceper, Klaten.

[12] Meladia Elok Purbarani dan Suminar., 2015., Analisis Rietvield Data Difraksi Kristobalit Hasil Sintesis dengan Metode Kopresipita, Jurusan Fisika, FMIPA, Institut Teknologi Sepuluh Nopember (ITS), Surabaya. 